Anna Boguszewska

https://doi.org.10.26881/ae.2018.15.02

ORCID: 0000-0003-0971-1258

Uniwersytet Marii Curie-Skłodowskiej

anna.boguszewska@poczta.umcs.lublin.pl

\title{
Przyczynek do poszukiwania genezy polskiej książki obrazkowej
}

\section{Wstęp}

Książka obrazkowa jest szczególnym typem książki ilustrowanej. Określenie „książka z obrazkami” nie jest dla niej wystarczające. Jej istotą jest zdublowany przekaz - przez obraz i słowo, często z poważną przewagą strony wizualnej. Jest to przekaz zależny wzajemnie, gdzie obraz całkowicie zastępuje słowa lub wzmacnia ich znaczenie i rozumienie. Charakter książki obrazkowej wyraża się w łączeniu specjalności sztuki użytkowej - takich jak grafika wydawnicza, typografia i ilustracja - w harmonijną i uzasadnioną formalnie jedność.

Książkę obrazkową (picture book, picturebook) adresowaną do dzieci powinien wyróżniać profesjonalizm opracowania edytorskiego i graficznego, gdyż to, co dziecko ogląda, ma niebagatelne znaczenie dla jego rozwoju. W zamierzeniach poznawczych, wychowawczych i kształcących książka ma stymulować rozwój dziecka. Dlatego ważne jest, aby była inspirująca poznawczo, budząca emocje, ciekawość, aby wpływała na wyobraźnię i rozwijała postawę estetyczną. Również problematyka tematyczna książki obrazkowej winna być zróżnicowana - obejmująca zagadnienia edukacyjne zarówno z zakresu świata przyrodniczo-geograficznego, jaki i z kultury. Szczególnie ważne mogą tu być społeczne wątki tematyczne określane jako „trudne”.

Zamierzeniem niniejszego opracowania jest zaprezentowanie materiału źródłowego, czasem zapomnianego, będącego chronologicznym przeglądem wybranych wydań książkowych, w których ilustracja ma znaczącą, równoprawną $\mathrm{z}$ tekstem rolę. Wykorzystano technikę analizy dokumentu zaczerpniętą z metodologii nauk historycznych. Wybrane publikacje książkowe adresowane do dzieci, ze względu na dwoisty kod przekazu, można kwalifikować jako książki obrazkowe. Wyboru dokonano spośród szczególnie bogatych w materiał ilustracyjny polskich 
wydawnictw z przełomu XIX i XX wieku oraz wydanych później. W ocenie autorki są to reprezentatywne utwory, świadczące o samorodnej drodze i ewolucji polskiej szkoły książki obrazkowej. Wszystkie wyprzedzają rok 1963, w którym to wydano jedną z najsłynniejszych książek obrazkowych XX wieku - autorską pozycję Tam, gdzie żyja dzikie stwory zaprojektowana przez Maurice’a Sendaka, wprowadzającą czytelnika w niezwykłą przygodę małego Maxa (Cackowska 2017). Warto tu wspomnieć wyprawę polskiego Mateuszka napisaną przez Stefanię Szuchową, a wydaną dwa lata wczesnej, w 1961 roku. Przygody Mateuszka barwnie i dynamicznie zilustrowała Janina Krzemińska (il. 1), stosując technikę akwareli oraz zabieg zatłuszczania podobrazia (Szuchowa 1961).

W historii Mateuszka i Maxa widać analogie w niezwykłej podróży i spotkaniu innych istot mających bezpośredni wpływ na kształtowanie się postawy bohatera i jego świadomość siebie. Mateuszek stwierdza:

Niech się o mnie nikt nie martwi

mam osiołka, wózek, bat.

Do widzenia babciu, mamo

Mateuszek jedzie w świat (Szuchowa 1961: [b.p.]).

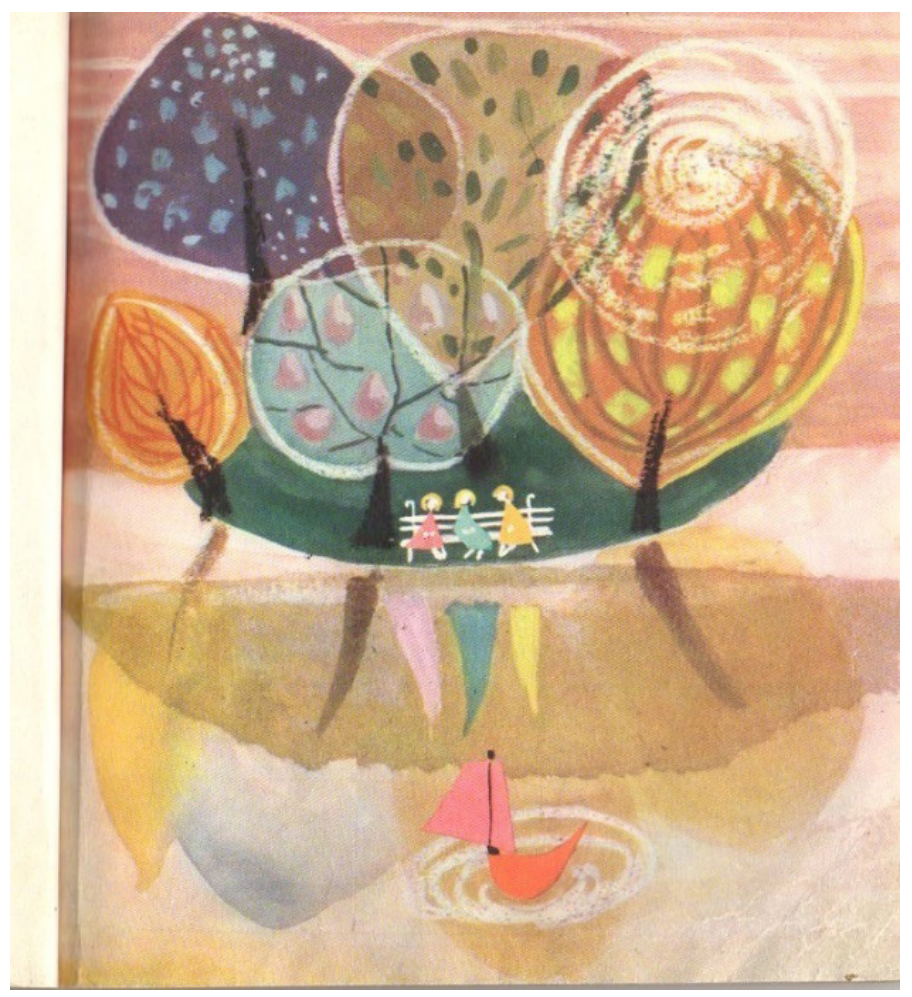

Il. 1. Ilustracja autorstwa Janiny Krzemińskiej w książce Stefanii Szuchowej Mateuszek na zaczarowanej wyspie z 1961 roku 
Mały Max podjął podobną wyprawę wyobraźni (il. 2). Wyobrażony świat przybiera formy rzeczywiste - rosnący las w pokoju, ocean i spotkanie stworów jest jak najbardziej realne:

a oceanem przypłynęła do Maxa jego własna łódka,

którą pożeglował przez noc i dzień, z tygodnia na tydzień, niemal na druga stronę roku, by dotrzeć tam,

gdzie żyją dzikie stwory (Sendak 2014: [b.p.])

\section{WHERE THE WILD THNGS ARE}

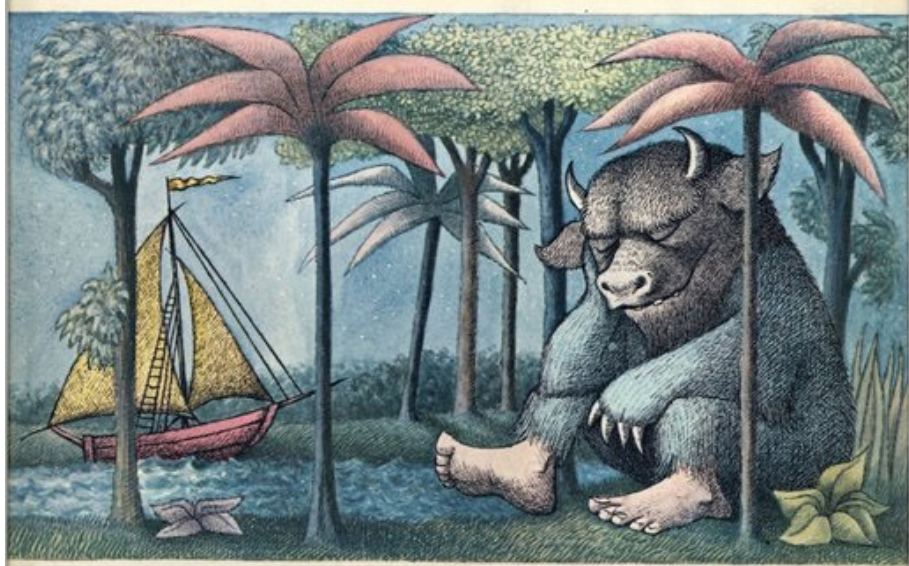

\section{STORY AND PICTURES BY MAURICE SENDAK}

Il. 2. Okładka oryginalnego wydania Where the Wild Things Are Maurice’a Sendaka z 1963 roku

Takie propozycje urzekają dzieci, trafiając w naturę ich wyobraźni i potrzebę fantazjowania. Pokrewne pomysły, chociaż zawierają inną dozę dydaktyzmu, uświadamiają dziecku wartość społecznych norm, których podstawy poznają w rodzinie. Jednocześnie nieposłuszeństwo bohatera i przekraczanie powszechnie obowiązujących norm jest dla niego tylko skuteczną lekcją życia i nie powoduje odrzucenia go przez najbliższych. To znakomity przykład wydarzeń, gdzie przekształcają się antywzorce postępowania, następuje refleksja oraz rozpoznawanie własnych emocji. Świat Mateuszka w wielu aspektach jest porównywalny ze światem Maxa. Książka obrazkowa jest pożytecznym narzędziem przekazu dla młodych odbiorców. Na tym przesłaniu oparto się, inicjując w latach pięćdziesiątych cykl „Świat w Obrazach”, któremu z racji imponującej wielkości w analizach poświęcono szczególne miejsce. 
Ze stanu badań nad książką obrazkową

Do klasyki powojennych znawców książki ilustrowanej oraz jej badaczy w Polsce należą specjaliści z różnych dziedzin nauki i sztuki: Andrzej Banach, Janusz Dunin, Janusz Sowiński, Stefan Szuman, Irena Słońska, Janina Wiercińska, Danuta Wróblewska. Problematyka ta zajmuje ważne miejsce w badaniach Anny Boguszewskiej, Małgorzaty Centner-Guz, Małgorzaty Komzy, Anieli Książek-Szczepanikowej, Beaty Mazepy-Domagały, Krzysztofa Migonia, Elżbiety Szefler, Anity Wincencjusz-Patyny i innych. U wymienionych badaczy pojawia się motyw tematyczny książki obrazkowej w kontekście analiz związanych z książką ilustrowaną. Janina Wiercińska zapoczątkowała w Polsce badania polskiej książki obrazkowej. Zagadnienia te rozwija Małgorzata Cackowska. Wyjątkowe znawstwo szaty graficznej książki dziecięcej, w tym obrazkowej, prezentują Grażka Lange, Krystyna Lipka-Sztarbałło oraz wielu innych twórców, artystów ilustratorów. Kluczowe publikacje dotyczące książki obrazkowej to opracowania monograficzne: Look! Polish Picturebook! oraz Ksiażka obrazkowa. Wprowadzenie.

\section{Poszukiwania genezy polskiej książki obrazkowej}

Umieszczenie zjawiska polskiej książki obrazkowej w kontekście historycznym jest bardzo istotne. Już na progu XX wieku Janina Mortkowiczowa zwróciła uwagę na wartości płynące z oglądu dzieł sztuki w procesie wychowania dzieci. Zdecydowanie podkreśliła potrzebę rozwijania percepcji i recepcji obrazu, stwierdzając: „Obrazki i książki obrazkowe, które od najmłodszych lat dostają się do rąk dziecka, wywierają poważny wpływ na rozwój estetyczny i mogą stać się pierwszorzędnym narzędziem wychowania estetycznego" (Mortkowiczowa 1904: 15). Również z racji rzetelności, aby nie przypisywać niesłusznie źródeł polskiej książki obrazkowej jedynie dokonaniom artystycznym w obcych kulturach (na przykład traktując jako pierwowzór wspomnianą książkę Where the Wild Things Are Sendaka), należy pamiętać o dziełach rodzimych. Janina Wiercińska za najwcześniejszą polską książkę obrazkową uznaje wydane w 1860 roku Bajki Stanisława Jachowicza z ilustracjami Wojciecha Gersona (ręcznie kolorowane drzeworyty). Edycję powtórzono w 1876 roku, w 1880 ukazały się Bajki i przypowieści Ignacego Krasickiego z - również ręcznie kolorowanymi - drzeworytami Ksawerego Pillatiego i Antoniego Zaleskiego. Jako prototyp całkowicie polskiej propozycji odpowiadającej rozumieniu książki obrazkowej można zaklasyfikować formę książki Bajka o Kasi i królewiczu autorstwa Lucjana Rydla wydaną w 1904 roku. Okładkę i ilustracje, które mają tu wiodący charakter i nawiązują do stylistyki ludowej, oraz liternictwo zaprojektował Stanisław Dębicki - wykorzystując duży, nowatorski format oraz narrację kolorem. Warto przytoczyć opinię Mieczysława Tretera powstałą 
po dwudziestu latach od wydania książki: „Stanisław Dębicki [...] przejawiał osobliwy talent w malowaniu dzieci, znowuż umiał odczuwać ich duszę, rozumieć odrębny świat ich zainteresowań, czemu znakomity dał wyraz w swych świetnych ilustracjach" (Treter 1924: 25). Ze współczesnej perspektywy Bajkę o Kasi i królewiczu można uznać za prekursorską dla polskiej książki obrazkowej, która wówczas znacznie częściej była odrzucana aniżeli doceniana przez krytyków i opinię społeczną.

Wydane w 1905 roku Jasełka Marii Konopnickiej w całościowym opracowaniu graficznym Jana Bukowskiego to kolejna udana polska propozycja opowiadania obrazem. Późniejsze tytuły zasługujące na uwagę w temacie książki obrazkowej, utrwalające nowy typ książki, to Książeczka Halusi Bronisławy Ostrowskiej z 1906 roku oraz Jak się dzieci w Bronowie bawity Konopnickiej z 1911 roku. W 1917 roku debiutuje Zofia Lubańska, późniejsza Stryjeńska, wydaną w wydawnictwie Warsztatów Krakowskich książką Pastorałki z siedmiu kolęd złożone, zdobioną dynamicznymi, pięknymi w formie ilustracjami.

Tadeusz Dobrowolski wyróżnia trzy zasadnicze kierunki w sztuce polskiego dwudziestolecia międzywojennego, których oddziaływanie było znamienne dla formy dziecięcej ilustracji książkowej. Były to kontynuacje form z okresu Młodej Polski, tworzenie nowego, czyli awangarda, oraz koloryzm (Dobrowolski 1989, Michalska 1986).

W latach dwudziestych założenia koncepcji „pięknej książki” skupiały się wokół perfekcji kompozycji typograficznej. Ewentualna obecność ilustracji oraz zdobników, najczęściej drzeworytniczych, warsztatowo i formalnie były podporządkowane liternictwu. Z istoty nie stanowiły koniecznego elementu pięknej książki, zatem dominowało „typograficzne” rozumienie kunsztu grafiki książki. W tym okresie powstają wytworne książki zgodne z preferowana ideą, opracowane przez Edmunda Bartłomiejczyka, które pretendują do kwalifikacji jako obrazkowe. W 1922 roku artysta zaprojektował do tekstu Józefa J. Kraszewskiego Dziad i baba w matrycy drzeworytniczej druk i ilustracje inspirowane stylistyką ludową. Nowatorstwo publikacji polegało na całościowym ujęciu architektonicznym formy książki i prowadzeniu narracji obrazem. Kolejny projekt z 1923 roku to narracyjna grafika ilustracyjna przenikająca się z tekstem Juliana Ejsmonda O Janku Kominiarczyku i dymiacym piecu króla Stasia, doceniona w 1929 roku na Powszechnej Wystawie Krajowej w Poznaniu złotym Medalem (il. 3).

Bogatą ilustrowaną szatę graficzną zaprojektowaną przez Zofię Stryjeńską otrzymały teksty Zofii Rogoszówny: Sroczka kaszkę warzyła, Gadki dziecięce spisane z ust ludu i wspomnień dzieciństwa, Heleny Sobańskiej Skąd krasnoludki dostały swoje czapeczki oraz Janiny Porazińskiej Jaś i Kasia. Artystka stworzyła dynamiczne i pełne humoru ilustracje o charakterystycznej stylistyce inspirowanej formizmem oraz polską sztuką ludową. 


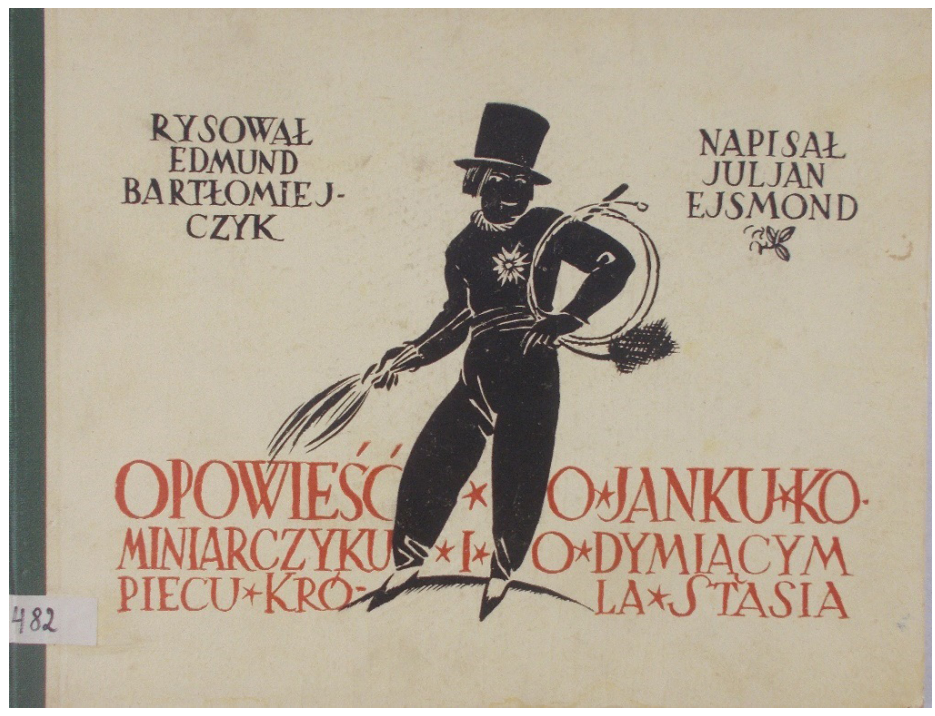

Il. 3. Okładka projektu Edmunda Bartłomiejczyka do książki Juliana Ejsmonda O Janku Kominiarczyku i dymiącym piecu króla Stasia z 1923 roku

Stanisław Bobiński opracował obrazkową opowieść do popularnej w dwudziestoleciu międzywojennym książki W Wojtusiowej izbie Janiny Porazińskiej (1925) oraz opowiadań Lucyny Krzemienieckiej wydanych w 1930 roku pod tytułem Łap-cap.

Podobnie wydano utwory wybrane z bogatej twórczości Marii Konopnickiej. Bogdan Nowakowski podaje treść tekstu w Szkolnych przygodach Pimpusia Sadełko (1928) oraz Filuś, Miluś i Kazia (1929) w formie narracyjnego wątku ilustracyjnego, wprowadzając lapidarność groteskowego rysunku i znakomity humor sytuacyjny.

JózefBirkenmajer jest pomysłodawcą serii książek tytułowanych jako obrazkowe warto je przypomnieć z tego właśnie względu - chociaż zakres rozumienia terminu „książka obrazkowa” w tym okresie nie pokrywa się z obecnym. Serię wydano w Poznaniu w Wydawnictwie Polskim Rudolfa Wagnera w 1931 roku. Każdy z krótkich, dowcipnych wierszyków oscylujących wokół jednej tematyki opatrzono całostronicową barwną ilustracją. Są to chromolitografie obcego pochodzenia, prawdopodobnie angielskiego. Można sądzić, że autor wierszy będący wybitnym tłumaczem literatury angielskiej i klasycznej miał szeroki wgląd w ówczesne wydawnictwa obce. Serie tworzą następujące tytuły: Tik-tak, Czy już znacie?, Kocham pieski, U krasnoludków, Przyjaciele. W każdej publikacji jest obecny podtytuł Książeczka obrazkowa. W Bibliotece Jagiellońskiej zachował się tomik Przyjaciele. Na każdej rozkładówce mieści się barwna ilustracja całostronicowa oraz stosowny wierszyk (il. 4). Opowiada o zabawnych zdarzeniach z życia kotów i psów, obrazując ich zachowaniem postawy czy postępowanie dzieci. 


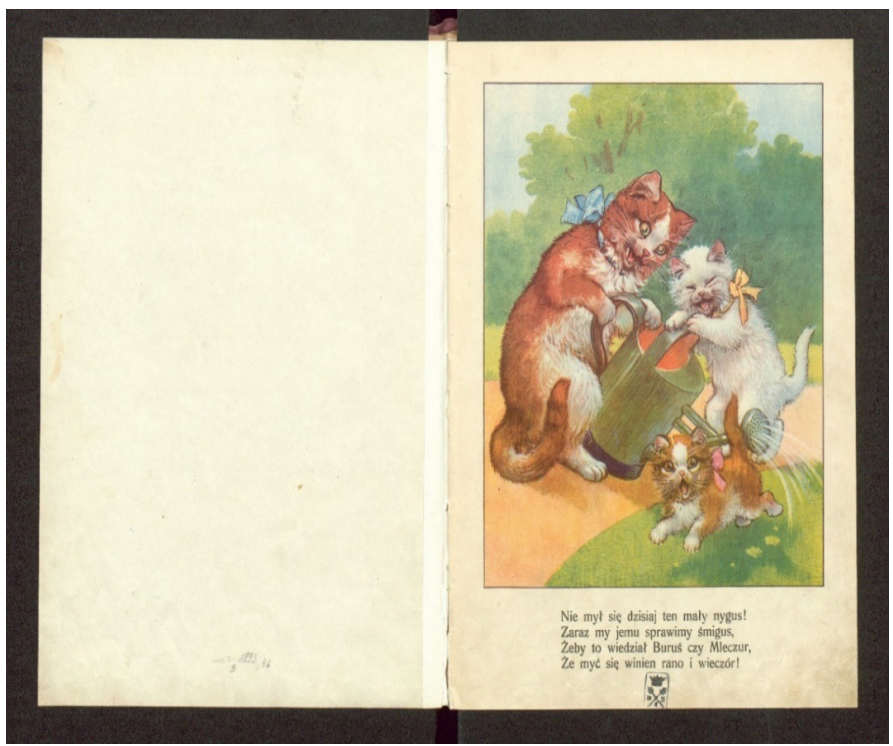

Il. 4. Karta rozkładowa książki Przyjaciele autorstwa Józefa Birkenmajera z 1931 roku

Książka obrazkowa będąca swoistym typem książki ilustrowanej stopniowo utrwalała swój byt i rozwijała się w kierunku przewagi narracji obrazem. W latach trzydziestych ilustracja ma zdecydowanie większy udział w tworzeniu formy książki dla dzieci'. W zasłużonym dla popularyzacji literackiej kultury polskiej wydawnictwie założonym przez Jakuba Mortkowicza w 1937 roku ukazuje się Tańcowała igła z nitka Jana Brzechwy w narracji plastycznej Franciszki Themerson. Wydanie zyskuje powodzenie, dlatego wznowienie następuje już w 1939 roku. W 1938 roku wydano znamienną dla rozwoju polskiej książki obrazkowej Lokomotywę Juliana Tuwima według projektu Jana Lewitta i Jerzego Hima. Zajęło się tym wydawnictwo Marka Przeworskiego, odziedziczone po ojcu Jakubie, które celowało w nowościach. Utwór ten na długo pozostał w Polsce wzorem nowoczesnej książki obrazkowej. W powojennych projektach graficznych Lokomotywy artystów Ignacego Witza, Jana Lenicy i Jana Marcina Szancera także jest obecna idea książki obrazkowej (Boguszewska 2013b).

${ }^{1}$ W 1937 roku w Paryżu na Międzynarodowym Kongresie Pedagogicznym nagrodzono metodykę i szatę graficzną polskich wydawnictw dla dzieci. 
Polska książka obrazkowa lat pięćdziesiątych.

Cykl „Świat w Obrazach”

Ważnym potwierdzeniem obecności książki obrazkowej w latach pięćdziesiątych było wydanie cyklu „Świat w Obrazach" ${ }^{2}$. Była to pierwsza powojenna seria przemawiająca obrazem i prowadząca obrazem narrację. Wydawana od roku 1950 pod patronatem i z rekomendacji Ministerstwa Kultury i Sztuki, była adresowana do grupy dzieci przedszkolnych. Zapotrzebowanie na tego typu publikacje było bardzo duże. Broszurowe książeczki, drukowane na sztywnym kartoniku, miały szeroki zasięg z racji wysokiego nakładu (250-300 tys.). Z kilkunastu pierwszych opracowanych tomików (Dziwne zwierzęta, Góry, Jesień, Największe zwierzęta, Ptactwo domowe [il. 5], Polskie stroje ludowe, Twoje miasto, W przedszkolu, Wiosna, Zabawa i zabawki, Zwierzęta domowe, Zima) niektóre w 1953 roku wznawiano już trzecim wydaniem. Cena tomiku - 3 zł - była znacznie wyższa na przykład od popularnej serii „Poczytaj mi Mamo”. Cykl realizowało Państwowe Wydawnictwo Literatury Dziecięcej Nasza Księgarnia.

Każdy tomik był autorską propozycją narracji obrazem bez tekstu. Artyści sami decydowali o tym, jaki temat zilustrują. Wydawnictwo współpracowało z ówcześnie najwybitniejszymi grafikami zaangażowanymi w ilustratorstwo dla najmłodszych.

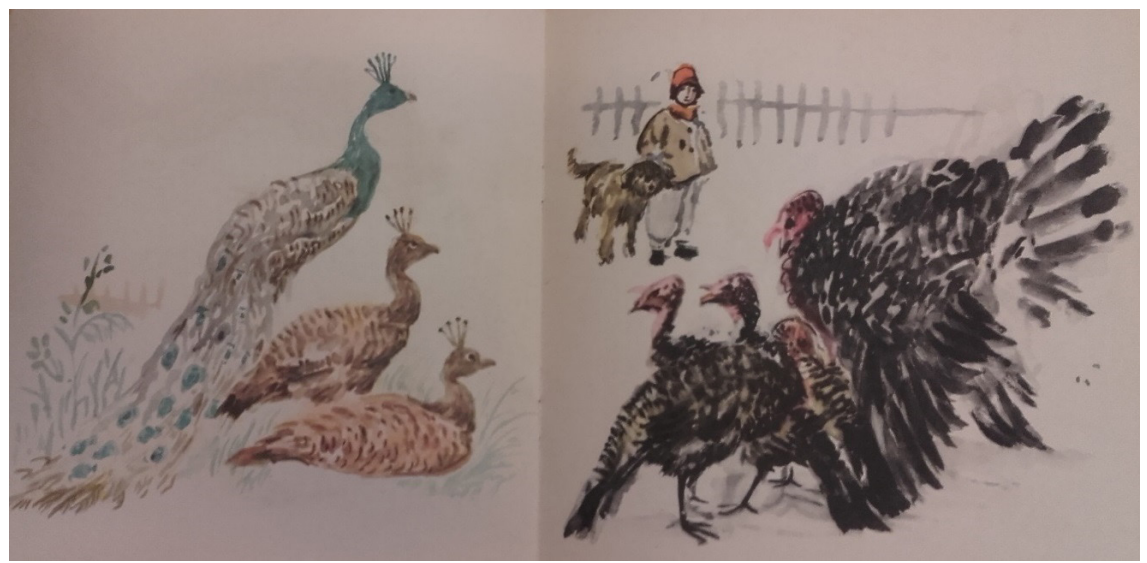

Il. 5. Karta rozkładowa w książce Józefa Czerwińskiego

Ptactwo domowe z 1956 roku

Poszczególne tomiki ilustrowali na przykład: Bohdan Bocianowski (Lato), Michał Bylina (Wieś), Józef Czerwiński (Ptactwo domowe, W wodzie), Janusz Jurewicz (Las, Skarby ziemi), Zofia Fijałkowska (Góry), Mateusz Gawryś (Port,

\footnotetext{
${ }^{2}$ Precedens emisji serii wydawniczej „Świat w Obrazach” miał miejsce w okresie dwudziestolecia międzywojennego. Zachowany „Cykl Przyrodniczy” zaproponowany przez Stanisława Gartkiewicza dotyczył zoo (nr 1). Narracje wizualne tworzyło ponad sto fotografii.
} 
Samoloty [il. 6]), Maria Hiszpańska (Jacek i jego rodzina), Jerzy Karolak (W jesieni), Ludwik Maciąg (Zwierzęta domowe), Konstanty Sopoćko (Twoje zwierzatka), Roman Owidzki (Bociany wracaja, Największe zwierzęta), Olga Siemaszko (Wiosna), Zbigniew Rychlicki (Pochód majowy, Węgiel) Zdzisław Witwicki (Warszawa), Ignacy Witz (Miasto).

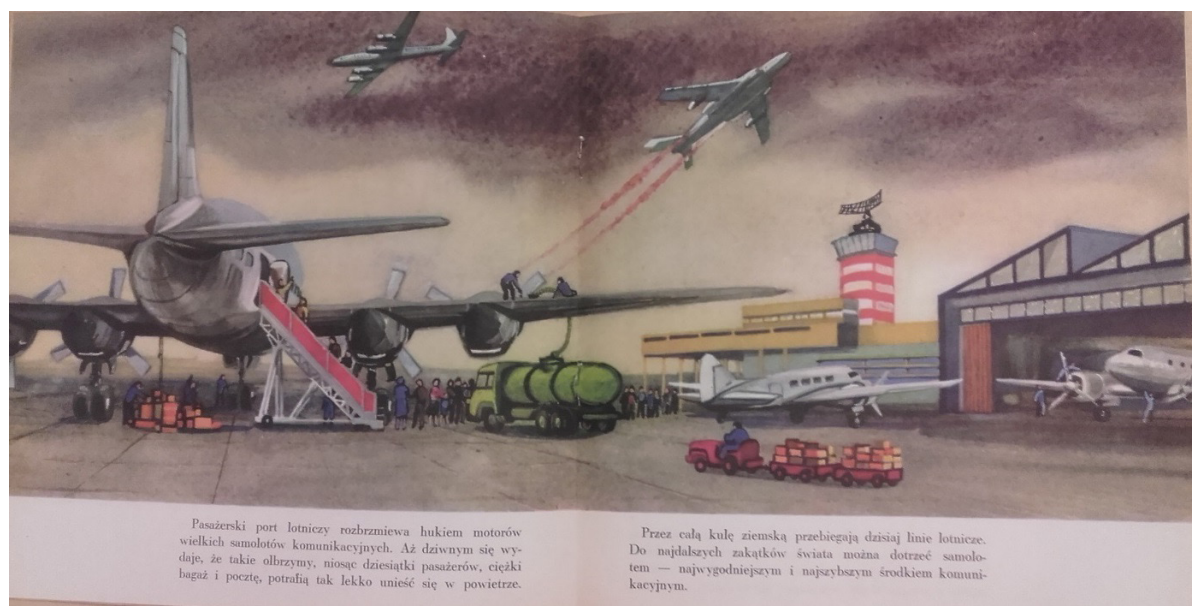

Il. 6. Karta rozkładowa w książce Mateusza Gawrysia Samoloty z 1956 roku

Jak wspomina Zdzisław Witwicki, kierownictwo redakcji artystycznej wydawnictwa nie do końca było zadowolone z efektów serii. Zamierzeniem było stworzenie książki artystycznej dla dzieci realizującej misję wychowania estetycznego. Często w narracji, doborze szczegółów przedstawień dominowała narzucająca się ideologizacja. Niejednokrotnie efekty projektów autorskich niweczyła jakość wydruku (Wywiad ze Zdzisławem Witwickim z 17 lutego 2018 roku - w posiadaniu A.B.).

Obowiązywał format zbliżony do kwadratu $(21 \mathrm{~cm})$, układ broszurowy, dwanaście kart-obrazów wydrukowanych na sztywnym kartonie w oprawie broszurowej. Były to książeczki beztekstowe, w kilku tomikach znalazły się krótkie opisy lub wierszyk (Cyrk, Port, Zima), w większości jest spis ilustracji. Okładka z barwną ilustracją zapowiadała tematykę, zazwyczaj podawano nazwisko ilustratora. Głównym narzędziem narracyjnym zawsze jest obraz - pamiętano, że odbiorca nie posiadł jeszcze umiejętności czytania. Projekt cyklu obejmował 24 tematy. Spełniały one również funkcję propagandową. Z biegiem lat cykl rozrósł się, w 1961 roku obejmował pięćdziesiąt motywów tematycznych. Seria „Swiat w Obrazach” nie miała własnego znaku graficznego, nie zawsze także jej nazwa była umieszczana na okładce (Jamróz-Stolarska 2014: 99-101). Podejmowano tematykę interesującą dla dzieci mieszkających zarówno na wsi, jak i w mieście. W założeniu książki miały bawić i edukować jednocześnie. Dostosowane do idei Jana Amosa Komeńskiego, autora popularnego podręcznika Świat $w$ obrazach, skąd zaczerpnięty jest tytuł serii, 
dostarczały wiedzy o otaczającym świecie zarówno najbliższym dla dziecka (Wiosna, Las, Lato, Zima, Zabawy i zabawki), jak i w dalszych jego kręgach (Port, Polskie stroje ludowe, U Eskimosów, Węgiel).

Wśród wątków tematycznych można wyróżnić przyrodę, gdzie prezentowano zwierzęta domowe i egzotyczne (Zwierzęta domowe, Największe zwierzęta), piękno pejzażu Polski (Bociany wracają, Góry, Łąki, Morze, Wisła, Warszawa) oraz świat wsi (Pola, Sad, Wieś, W jesieni). Inny wątek dotyczył rozwoju techniki widocznego w zakładach pracy, miastach i na wsi (Budowa, Jada samochody, Port, Łodzie, statki i okręty, Samoloty, Wegiel). Prezentowano też kulturę Polski (Polskie stroje ludowe) i innych, tzw. bratnich narodów (Chiny). Były też książeczki bezpośrednio związane z życiem dziecka i jego środowiskiem rodzinnym (Jacek i jego rodzina, Przyjaciel pies, $W$ przedszkolu). Niezależnie od podjętego tematu w publikacjach panowała zasada zgodna z ideologicznymi wytycznymi Polski Ludowej. Indoktrynacja obrazem w omawianej serii jest bardzo czytelna zarówno w warstwie wykorzystywanego w narracji realizmu, jak i doboru treści i ich wizualnej interpretacji.

Mimo ograniczeń związanych $\mathrm{z}$ propagandowymi założeniami socrealizmu artyści tworzyli narracje obrazem interesujące artystyczne. Do takich należy malarska propozycja debiutującej wówczas Marii Mackiewicz składająca się z dziesięciu obrazów. Ich spis na końcu książki stanowi swoisty opis egzotycznej historii chłopca imieniem Tugto. „Na Dalekiej Północy wśród śniegów i lodów stoją śniegowe domki. Mały Tugto bawi się przed domem”, „Matka przygotowała obiad - gorącą zupę z ryby”, „Tugto karmi renifera”, „Eskimosi polują na niedźwiedzia (rozkładówka)”, „Tugto prowadzi psi zaprzęg (rozkładówka)”, „Foki wyszły na brzeg morza”, „To dziwne zwierzę żyjące na północy - to wół piżmowy”, „Ojciec Tugto poluje na morsy”, „Na morzu widać statek wielorybniczy ciągnący za sobą upolowane wieloryby”, „W kraju Eskimosów noc trwa sześć miesięcy”, „Od czasu do czasu ciemności rozjaśnia blask na niebie - to zorza polarna" (Mackiewicz 1956: [b.p.]). Podobnie malarska i dynamiczna w kompozycji oraz subtelna w kolorze była propozycja Danuty Heintze Sad oraz Góry Fijałkowskiej. Ludwik Maciąg zaprezentował domowe zwierzęta bardziej znane wiejskim dzieciom z kunsztem malarskim i dozą humoru. Mateusz Gawryś $\mathrm{w}$ wykonanych tomikach posługiwał się swobodą warsztatu akwarelisty dostosowanego do realistycznego rysunku.

Eugenia Różańska w tomiku Łąka opowiedziała z wnikliwością wytrawnego biologa o tajnikach tej biocenozy. Zestawiła malarskie obrazy z tablicowym przedstawieniem okazów należnym książce edukacyjnej. Książeczka $W$ wodzie Czerwińskiego prezentuje mieszkańców wód również w formie plansz edukacyjnych.

Interesującym artystycznie tomikiem serii „Swiat w Obrazach” jest Zima Gustawa Majewskiego z tekstem Wiery Bodalskiej (Hanna Czajkowska jest autorką beztekstowego tomiku w tej serii o tym samym tytule). To jedna z pierwszych realizacji graficznych. Rzadko wykorzystywano teksty autorskie - było tak jeszcze w propagandowej książeczce Budowa do tekstu Romana Pisarskiego zilustrowanej przez Janusza Jurjewicza (1954). Tomiki zawierały bardziej opisowe lub lapidarne 
spisy ilustracji. W tomiku Cyrk zamiast spisu znajduje się opis odpowiadający dynamice groteskowych ilustracji Piotra Bary:

Dobry wieczór, Szanowna Publiczności! Na pewno widzieliście wczoraj na ulicy ogromnego, szarego słonia, za zanim pana z trąbą, który ogłaszał przybycie naszego cyrku. I teraz właśnie zobaczycie piękne, jedyne, niezapomniane przedstawienie... Patrzcie! Wygodnie jest jechać autem, pociągiem czy autobusem - ale czy ktoś z Was umie tak jak panna Zofia galopować na koniu, stojąc na jednej nodze? Wy, trzymając w obu rękach jeden talerz - tłuczecie go, przyznajcie, że pan w cylindrze jest od Was o wiele zręczniejszy (Baro 1957: [b.p]).

Dalej następowały kolejne przekonywujące zachęty do podziwiana innych artystów cyrkowych (il. 7).

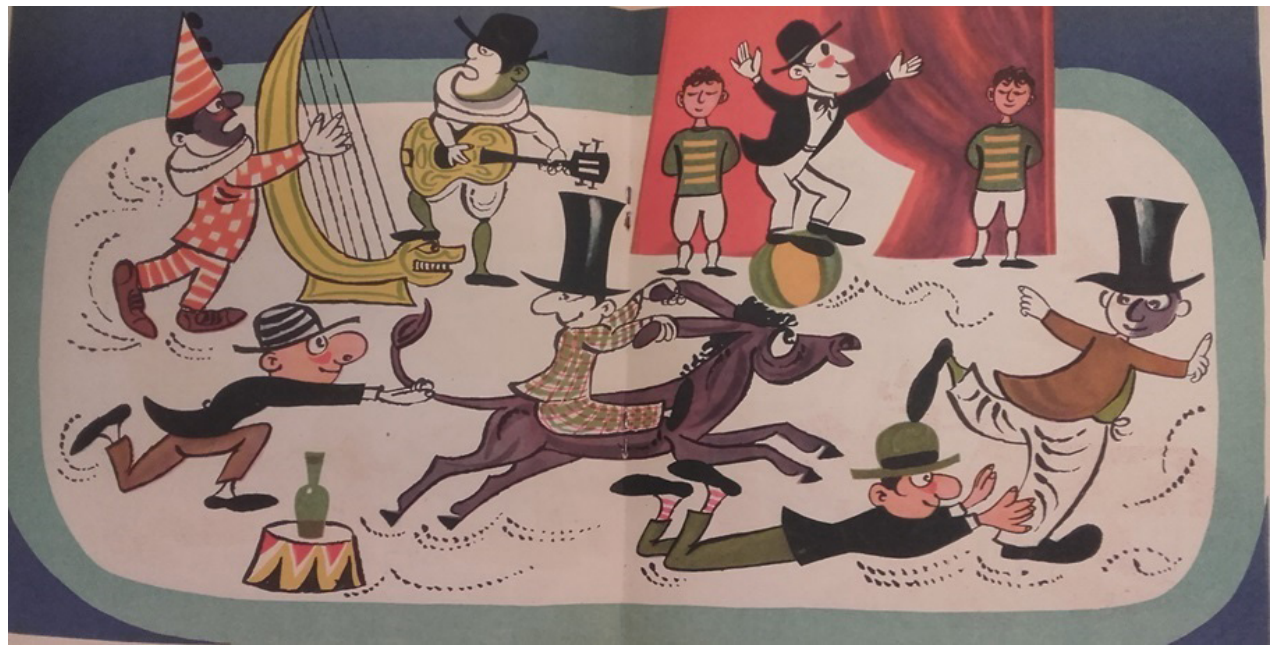

\section{Il. 7. Ilustracja Piotra Baro z Cyrku z 1957 roku}

Typowym przykładem przekazu grafiką książki obrazkowej z omawianej serii może być Wegiel w opracowaniu ilustratorskim Rychlickigo. Interesująca jest plastyka poszczególnych obrazów, dynamizm form i barw, operowanie kontrastem. Zastosowano bogatą kolorystykę. Treści obrazów przekazywały afirmację pracy, poświęcenie dla kraju, realizując założenia polityki edukacyjnej tego okresu. Ilustratorzy serii dysponowali wielkim potencjałem malarskim, co przekładało się na płynność form opisywanych łagodną plamą i kreską, gubiących sztywność schematycznego przedstawiania stosowanego realizmu.

Schyłek XX wieku jest naznaczony kryzysem, znacznym obniżeniem poziomu poligraficznego, edytorskiego i artystycznego książki adresowanej do dzieci. Lata po 2000 roku przyniosły jej odrodzenie. Przyczyniła się do tego twórczość wielu artystów, wśród nich Iwony Chmielewskiej, Marty Ignerskiej, Aleksandry i Daniela 
Mizielińskich, Marianny Oklejak czy Krystyny Lipki-Sztarbałło. Wielu artystów nowego pokolenia specjalizuje się $\mathrm{w}$ formie książki obrazkowej, zdobywając zasłużone laury, eksponując jej wysoką jakość.

\section{Zakończenie}

W zaprezentowanym przeglądzie ilustrowanych książek dla najmłodszych można upatrywać genezy polskiej książki obrazkowej. Wybór, z konieczności dość wąski, zawiera reprezentatywne utwory, świadczące o tworzeniu się niezależnej polskiej szkoły książki obrazkowej, zachowującej rodzimą odrębność mimo obcych wpływów. Książki wychodzące w serii „Świat w Obrazach”, masowo wydawanej po drugiej wojnie światowej, w świetle przyjętych kryteriów można uznać za obrazkowe. W okresie rozwoju polskiej szkoły ilustracji książka obrazkowa reprezentowała znakomity poziom. Swój talent i siły twórcze oddawało jej wielu znakomitych artystów (Boguszewska 2013a, Wincencjusz-Patyna 2008). Nadmienić jednak należy, że bez doświadczeń twórczych artystów międzywojnia nie byłby możliwy tak efektowny późniejszy rozwój polskiego ilustratorstwa. Genezy polskiej książki obrazkowej należy upatrywać również w tym okresie.

\section{Literatura}

Boguszewska A., 2013a, Ilustracja i ilustratorzy lektur dla uczniów w młodszym wieku szkolnym w Polsce w latach 1944-1989, Lublin: Wydawnictwo UMCS.

Boguszewska A., 2013b, Projekty graficzne pozapodręcznikowego wyboru ksiązek zalecanych do edukacji elementarnej w Polsce w latach 1918-1945. Materiaty do: Projekty graficzne pozapodrecznikowego wyboru ksiązek zalecanych do edukacji elementarnej w Polsce w latach 1918-1945, CD-ROM, Lublin: Wydawnictwo UMCS.

Cackowska M., 2017, Współczesna ksiażka obrazkowa - pojęcie, typologia, badania, teorie, konteksty, dyskursy [w:] Ksiażka obrazkowa - wprowadzenie, red. M. Cackowska, H. Dymel-Trzebiatowska, J. Szyłak, Poznań: Wydawnictwo Fundacji Instytut Kultury Popularnej.

Cackowska M., Dymel-Trzebiatowska H., Szyłak J. (red.), 2017, Książka obrazkowa - wprowadzenie, Poznań: Wydawnictwo Fundacji Instytut Kultury Popularnej.

Cackowska M., Wincencjusz-Patyna A., 2016, Look! Polish Picturebook!, trans. A. MorozDarska, Gdańsk: The Baltic Sea Cultural Centre.

Dobrowolski T., 1989, Malarstwo polskie ostatnich dwustu lat, Wrocław: Zakład Narodowy im. Ossolińskich.

Jamróz-Stolarska E., 2014, Serie literackie dla dzieci i młodzieży w Polsce w latach 19451989, Warszawa: Wydawnictwo Stowarzyszenia Bibliotekarzy Polskich.

Michalska K., 1986, Nurt tradycyjny w ilustracji książek dziecięcych dwudziestolecia międzywojennego, „Biuletyn Historii Sztuki”, nr 1. 
Mortkowiczowa J., 1904, O wychowaniu estetycznym, Warszawa: Wydawnictwo G. Centnerszwer i S-ka.

Treter M., 1924, Stanisław Dębicki (1866-1924), „Sztuki Piękne”, nr 25.

Wincencjusz-Patyna A., 2008, Stacja Ilustracja. Polska ilustracja książkowa 1950-1980. Artystyczne kreacje i realizacje, Wrocław: Akademia Sztuk Pięknych im Eugeniusz Gepperta-Instytut Historii Sztuki Uniwersytetu Wrocławskiego.

Wywiad ze Zdzisławem Witwickim z 17 lutego 2018 roku - w posiadaniu A.B.

Materiały źródłowe

Badalska W., 1952, Zima, il. G. Majewski, Warszawa: Nasza Księgarnia.

Balicka H., 1958, Pies przyjaciel, Warszawa: Nasza Księgarnia.

Baro P., 1957, Cyrk, Warszawa: Nasza Księgarnia.

Birkenmajer J., 1931, Przyjaciele. Książeczka obrazkowa, Poznań: Wydawnictwo Polskie R. Wagnera.

Bocianowski B., 1954, Lato, Warszawa: Nasza Księgarnia.

Bylina M., 1954, Wieś, Warszawa: Nasza Księgarnia.

Czajkowska H., 1960, Zima, Warszawa: Nasza Księgarnia.

Czerwiński J., 1955, W wodzie, Warszawa: Nasza Księgarnia.

Czerwiński J., 1956, Ptactwo domowe, Warszawa: Nasza Księgarnia.

Fijałkowska Z., 1952, Góry, Warszawa: Nasza Księgarnia.

Gawryś M., 1956a, Port, Warszawa: Nasza Księgarnia.

Gawryś M., 1956b, Samoloty Warszawa: Nasza Księgarnia.

Heinzke D., 1956, Sad, Warszawa: Nasza Księgarnia.

Hiszpańska M., 1952, Jacek i jego rodzina, Warszawa: Nasza Księgarnia.

Jurewicz J., 1952, Las, Warszawa: Nasza Księgarnia.

Jurewicz J., 1956, Skarby ziemi, Warszawa: Nasza Księgarnia.

Karolak J., 1956, W jesieni, Warszawa: Nasza Księgarnia.

Kraszewski, 1922, Dziad i baba, projekt E. Bartłomiejczyk, Warszawa: Ludwik Fiszer.

Maciąg L., 1956, Zwierzęta domowe, Warszawa: Nasza Księgarnia.

Mackiewicz M., 1956, U Eskimosów, Warszawa: Nasza Księgarnia.

Mieszkowska A., 1954, Polskie stroje ludowe, Warszawa: Nasza Księgarnia.

Orłowska M., 1954, Zabawa i zabawki, Warszawa: Nasza Księgarnia.

Owidzki R., 1954, Największe zwierzęta, Warszawa: Nasza Księgarnia.

Owidzki R., 1956, Bociany wracaja, Warszawa: Nasza Księgarnia.

Pisarski R., 1954, Budowa, il. J. Jurjewicz, Warszawa: Nasza Księgarnia.

Różańska E., 1952, Łąka, Warszawa: Nasza Księgarnia.

Rychlicki Z., 1952, Pochód majowy, Warszawa: Nasza Księgarnia.

Rychlicki Z., 1956, Węgiel, Warszawa: Nasza Księgarnia.

Sendak M., 2014, Tam, gdzie żyja dzikie stwory, tłum. J. Jędryas, Warszawa: Wydawnictwo

Dwie Siostry.

Siemaszko O., 1954, Wiosna, Warszawa: Nasza Księgarnia.

Sopoćko K.J., 1952, Twoje zwierzątka, Warszawa: Nasza Księgarnia.

Szuchowa S., 1961, Mateuszek na zaczarowanej wyspie, Warszawa: Nasza Księgarnia. 
Witwicki Z., 1955, Warszawa, Warszawa: Nasza Księgarnia.

Witz I., 1952, Miasto, Warszawa: Nasza Księgarnia.

Zawidzka W., 1954, W przedszkolu, Warszawa: Nasza Księgarnia.

\section{Streszczenie}

Niniejsze opracowanie prezentuje materiał źródłowy dotyczący polskich książek ilustrowanych o charakterze obrazkowym. Wybór zaczerpnięty został z polskich wydawnictw. Sięgnięto po książki z przełomu XIX i XX wieku oraz wydane później. Wszystkie wyprzedzają 1963 rok, w którym to wydano jedną z najsłynniejszych książek obrazkowych XX wieku zaprojektowaną przez Maurice’a Sendaka. Wykorzystano technikę analizy dokumentu. Zaprezentowany materiał źródłowy wskazuje na genezę polskiej książki obrazkowej.

\section{Słowa kluczowe}

książka ilustrowana, książka obrazkowa, książka XIX wieku, książka XX wieku

\section{Summary}

A contribution to the search for the genesis of the Polish picture book

Main meaning of this description is to present sources of Polish illustrated books for children in order of illustrations. All books are chosen from Polish publishing houses from XIX and XX century and later. All of them published after 1963 the year of publishing the most popular illustrated book designed by Maurice Sendak. Used technique is based on document analysis. Presented sources shows Polish illustrated books genesis.

Keywords

illustrated book, picture book, book of XIX century, book of XX century 